\title{
IMPLEMENTASI ALGORITMA TOPSIS DAN METODE EUCS UNTUK PENGUJIAN SISTEM PENILAIAN KINERJA PEGAWAI PADA LABORAN FAKULTAS TEKNOLOGI INFORMASI UKSW SALATIGA
}

\author{
Andreas Arga Rinjani Saputro ${ }^{1}$, Kristoko Dwi Hartomo*2 \\ ${ }^{1,2}$ Fakultas Teknologi Informasi, Universitas Kristen Satya Wacana \\ Email: ${ }^{1}$ rinjaniyou1998@gmail.com, ${ }^{2}$ kristoko@uksw.edu \\ *Penulis Korespondensi
}

(Naskah masuk: 13 Agustus 2019, diterima untuk diterbitkan: 26 November 2020)

\begin{abstract}
Abstrak
Pegawai laboratorium merupakan tenaga kerja kependidikan yang membantu proses pembelajaran mahasiswa dalam bagian vokasi dan akademik. Dalam menjalankan pekerjaannya, pegawai laboratorium terkadang masih belum maksimal. Sehingga kepala sarana \& prasarana dan supervisor harus mengontrol pegawai untuk memastikan pegawai berkerja dengan baik. Untuk mengatasi permasalahan dalam pegawai laboratorium serta membantu dalam memanajemen kinerja, dibuatlah sistem informasi berbasis website yang berisi implementasi algoritma TOPSIS pada penilaian kinerja pegawai laboratorium. Terdapat enam kriteria penilaian pegawai laboratorium yang terdiri dari kedisiplinan, tanggung jawab, kerja tim, skill, akademik, dan komunikasi. Hasil akhir penelitian berupa nilai preferensi $(\mathrm{Vi})$ setiap alternatif, dimana terdapat nilai preferensi tertinggi yaitu 1 yang diperoleh 3 dari 12 orang pegawai pada pengujian algoritma TOPSIS. Penyajian sistem informasi dilakukan dengan database yang ditampilkan menggunakan desain dashboard yang tepat digunakan untuk manajemen data. Pengujian EUCS pada website sistem informasi adalah 3.41 dari total nilai kepuasan (4) yang tergolong dalam kategori puas, sehingga dianggap layak dan diterima oleh user.
\end{abstract}

Kata kunci: Pegawai laboratorium, Penilaian Kinerja, TOPSIS, Sistem Informasi

\section{IMPLEMENTATION OF THE TOPSIS ALGORITHM AND EUCS METHOD FOR EMPLOYEE PERFORMANCE RATING SYSTEM ON THE LABORAN FAKULTAS TEKNOLOGI INFORMASI UKSW SALATIGA}

\begin{abstract}
Laboratory employee is a education labor which help process learning college student within part of vocational and academic. In carrying out his work, laboratory employee sometimes it's still not optimal. So that the head of facilities \& infrastructure and supervisor must control the employee to make sure employees are working well. For counter the problem in laboratory employee and help in performance management, made information system based on website which contain implementation of the TOPSIS algorithm on performance rating of the laboratory employee. There are six laboratory employee rating criteria which consisting of dicipline, responsible, team work, skill, academic, and communication. Last result of the research is the form of preference values (Vi) every alternatif, where there is highest preference value is 1 which is obtained 3 out of 12 employee of the TOPSIS algorithm testing. Presentment of the information system perform with database and displayed using dashboard design which exact used for present data management. EUCS testing on information system website is 3.41 from total satisfaction value (4) which classified of satisfied categori, so that good considered and accepting by user.
\end{abstract}

Keywords: Laboratory employee, Performance Rating, TOPSIS, Information System

\section{PENDAHULUAN}

Pegawai laboratorium merupakan tenaga kerja kependidikan yang membantu proses pembelajaran mahasiswa dalam bagian vokasi dan akademik strata $0,1,2$ dan 3 serta penelitian tugas akhir di laboratorium. Keberadaan pegawai laboratorium sangatlah penting dalam menentukan keberhasilan akademik mahasiswa. Setidaknya pegawai laboratorium harus memiliki hard skills dan soft skills yang memadai. Inisiatif, ketekunan, kreatifitas, kecakapan dan keterampilan serta pengetahuan, untuk membantu efisiensi dan efektifitas serta produktifitas dari laboratorium yang dikelola oleh perguruan tinggi (Kependidikan, 2014). 
Penilaian kinerja merupakan cara pengukuran kontribusi - kontribusi dari individu dalam instansi yang dilakukan terhadap organisasi. Pengukuran kinerja pegawai sangat penting untuk evaluasi dan peningkatan kualitas sumber daya manusia. Nilai penting dari penilaian kinerja adalah menyangkut penentuan tingkat kontribusi individu atau kinerja yang diekspresikan dalam penyelesaian tugas - tugas yang menjadi tanggung jawabnya (Shaout \& Yousif, 2014). Dalam melakukan penilaian kinerja, sistem pendukung keputusan mampu memberikan hasil dari tingkat kinerja setiap pegawai. Sehingga kepala sarana \& prasaran dan supervisor dapat menjadikan hasil keputusan tersebut untuk memanajemen kinerja pegawai laboratorium.

Algoritma TOPSIS merupakan algoritma sistem pendukung keputusan dengan banyak kriteria, yang mempertimbangkan jarak terhadap solusi ideal positif dan jarak terhadap solusi ideal negatif dengan mengambil jarak terdekat dari solusi ideal positif dan jarak terpanjang dari solusi ideal negatif, sehingga memperoleh alternatif nilai preferensi dari perbandingan terhadap jarak relatifnya (DSN, 2015). Konsep TOPSIS ini sederhana, mudah dipahami, perhitungan yang efisien dan memiliki fungsi untuk melakukan penilaian kinerja pegawai dari alternatif alternatif keputusan secara matematis serta penilaian kinerja dilakukan berdasarkan bobot pada kriteria yang ditentukan.

Penelitian mengenai penerapan algoritma TOPSIS dalam Sistem Pendukung Keputusan Pemberian Pinjaman pada Koperasi Karyawan yang dilakukan oleh tati mardiana (2017), menjelaskan kegunaan algoritma TOPSIS juga sebagai metode pendukung keputusan pemilihan karyawan yang layak diberi pinjaman. Hasil penelitian dengan algoritma TOPSIS menentukan karyawan yang layak menerima pinjaman koperasi berdasarkan penilaian kinerja setiap karyawan (Mardiana, 2017).

Penelitian mengenai Penilaian Kinerja Dosen dengan studi kasus AMIK Mitra Gama yang dilakukan sebelumnya oleh Candra Surya (2018), menjelaskan kegunaan algoritma TOPSIS sebagai sistem pengambilan keputusan penilaian kinerja. Hasil penelitian membuktikan bahwa sistem pengambilan keputusan merekomendasikan untuk mengevaluasi kinerja dosen (Surya, 2018).

Dilihat dari tingkat banyaknya kebutuhan dari program studi yang ada di Fakultas Teknologi Informasi dalam melaksanakan kegiatan perkuliahan serta keperluan proses akreditasi BAN-PT sangatlah didukung oleh laboratorium. Laboratorium ini diorganisir oleh kepala sarana \& prasarana yang membawahi supervisor dan pegawai laboratorium sebagai pelaksananya. Di dalam melaksanakan pekerjaannya, pegawai laboratorium terkadang masih belum maksimal. Sehingga kepala sarana \& prasarana dan supervisor harus mengontrol kinerja pegawai untuk memastikan pegawai berkerja dengan baik. Penilaian kinerja digunakan untuk mengontrol kinerja pegawai laboratorium secara jelas dan terdata. Dengan melakukan penilaian kinerja, kepala sarana \& prasarana dan supervisor bisa mengetahui tingkat kinerja pegawai pada setiap periode guna memanajemen kinerja para pegawai. Salah satu metode yang tepat untuk penilaian kinerja yaitu dengan algoritma TOPSIS.

Berdasarkan permasalahan tersebut, maka dilakukan penelitian dengan mengimplementasikan algoritma TOPSIS pada sistem informasi penilaian kinerja pegawai laboratorium Fakultas Teknologi Informasi Universitas Kristen Satya Wacana Salatiga. Dengan adanya implementasi algoritma TOPSIS pada penilaian kinerja pegawai laboratorium secara perseorangan menjadi penting untuk sebagai tolak ukur dasar kemampuan setiap pegawai laboratorium dan menjadi evaluasi untuk meningkatkan kinerja serta menjadi sarana untuk memanajemen sumber daya manusia, guna menjaga kualitas dan kinerja pegawai laboratorium.

Penelitian yang dilakukan oleh Hilman Nuril Hadi dan Wayan Firdaus Mahmudy (2015) yang berjudul Penilaian Prestasi Kinerja Pegawai Menggunakan Fuzzy Tsukamoto. Penelitian ini mengimplementasi Fuzzy Tsukamoto pada penilaian kinerja pegawai pada suatu perusahaan. Hasil penelitian memberikan akurasi sebesar $84 \%$ pada percobaan sebanyak 25 data pegawai, dimana fuzzy ini disarankan menambah fuzzy neuro untuk optimalisasi jumlah kriteria pada penilaian kinerja pegawai (Hadi \& Mahmudy, 2015).

Penelitian yang dilakukan oleh Merlien N. Febriyati dkk (2016) yang berjudul Perbandingan SAW dan TOPSIS untuk Open Recruitment Warga Laboratorium Teknik Informatika di Universitas Trunojoyo Madura. Penelitian ini menguji akurasi antara algoritma SAW dan algoritma TOPSIS dalam perekrutan warga laboratorium dari mahasiswa mahasiswa yang berprestasi. Hasil pengujian kedua algoritma, menunjukan nilai kecocokan alternatif dari algoritma SAW sebesar 33,33\% dan jumlah nilai kecocokan alternatif real sebesar 93,33\%. Sedangkan nilai kecocokan alternatif dari algoritma TOPSIS sebesar 46,67\% dan jumlah nilai kecocokan alternatif real sebesar $100 \%$. Sehingga algoritma TOPSIS memiliki akurasi yang baik daripada algoritma SAW (Febriyati, Sophan \& Yunitarini, 2016).

Penelitian yang dilakukan oleh Bayu Firmanto dkk (2016) yang berjudul Perbandingan Kinerja Algoritma Promethee dan TOPSIS untuk Pemilihan Guru Teladan. Penelitian ini membandingkan dua algoritma yang digunakan untuk penilaian kinerja, dimana algoritma Promethee dan algoritma TOPSIS. Hasil perbandingan dari kedua algoritma ini menunjukan algoritma TOPSIS memiliki akurasi yang baik daripada algoritma Promethee, dimana akurasi nilai precision, recall, accuracy dan error rate untuk Promethee masing - masing 91\%, 54\%, $88 \%$ dan $11 \%$. Sedangkan algoritma TOPSIS memiliki akurasi nilai precision, recall, accuracy dan 
error rate masing - masing 90\%, 94\%, 74\% dan 5\% (Firmanto, Soekotjo \& Dachlan, 2016).

Penelitian yang dilakukan oleh Asti Shofi Damayanti dkk (2018) yang berjudul Evaluasi Kepuasan Pengguna Aplikasi Tapp Market Menggunakan Metode EUCS. Penelitian ini menguji aplikasi Tapp Market menggunakan metode EUCS. Metode EUCS menghasilkan nilai variabel penilaian yang berbeda - beda sesuai dengan hasil pengujian. Diperoleh pada variabel Content dengan $74,7 \%$ dari hasil pengujian 100 kuesioner. Sehingga pengguna merasa puas dengan Content aplikasi Tapp Market (Damayanti, Mursityo \& Herlambang, 2018).

Penelitian yang dilakukan oleh Asih Prasetyowati dan Roro Kushartanti (2018) yang berjudul User Satisfaction Analysis of Primary Care Information Systems in Semarang City with EUCS Model. Penelitian ini menganalisis sistem informasi Primary Care untuk mengetahui tingkat kepuasan pengguna BPJS. Analisis membuktikan dengan metode EUCS sistem informasi dapat diterima oleh user, dimana hasil analisis mendapat nilai 75,5 yang termasuk dalam kategori puas (Prasetyowati \& Kushartanti, 2018).

Berdasarkan penelitian penilaian kinerja dengan algoritma yang sudah diteliti sebelumnya, keterbaruan penelitian ini menggunakan algoritma TOPSIS, dimana algoritma ini merupakan algoritma sistem pendukung keputusan dengan banyak kriteria. Algoritma TOPSIS dipilih karena memiliki akurasi yang baik daripada algoritma Promethee dan algoritma SAW yang digunakan juga untuk penilaian kinerja. Pengujian sistem informasi menggunakan metode EUCS yang memiliki kemampuan untuk menganalisis kepuasan user. Selain itu, pada penelitian ini menggunakan studi kasus penilaian kinerja pegawai laboratorium yang terdapat pada Fakultas Teknologi Informasi Universitas Kristen Satya Wacana Salatiga dengan kriteria yang sebagian besar disamakan dengan kriteria pegawai yang ada di universitas, sehingga bisa menjadi prototype untuk sistem penilaian kinerja pegawai laboratorium yang ada di Universitas Kristen Satya Wacana.

\section{METODE PENELITIAN}

Penelitian dilakukan dengan menggunakan algoritma TOPSIS. Algoritma TOPSIS melakukan penilaian dengan konsep banyak kriteria, sehingga penilaian mempertimbangkan hasil relatif dari jarak solusi ideal positif dan negatif. Proses penelitian implementasi algoritma TOPSIS dilakukan dengan berbagai tahapan yang saling berhubungan. Berikut merupakan gambar metodologi penelitian yang terdapat pada gambar 1 .

Data penilaian kinerja pegawai laboratorium menggunakan data primer, yang diperoleh dengan memberikan kuesioner terhadap salah satu supervisor yang bertugas untuk menilai pada periode tersebut. Terdapat 12 data pegawai pada pengujian algoritma TOPSIS seperti pada tabel 2 .

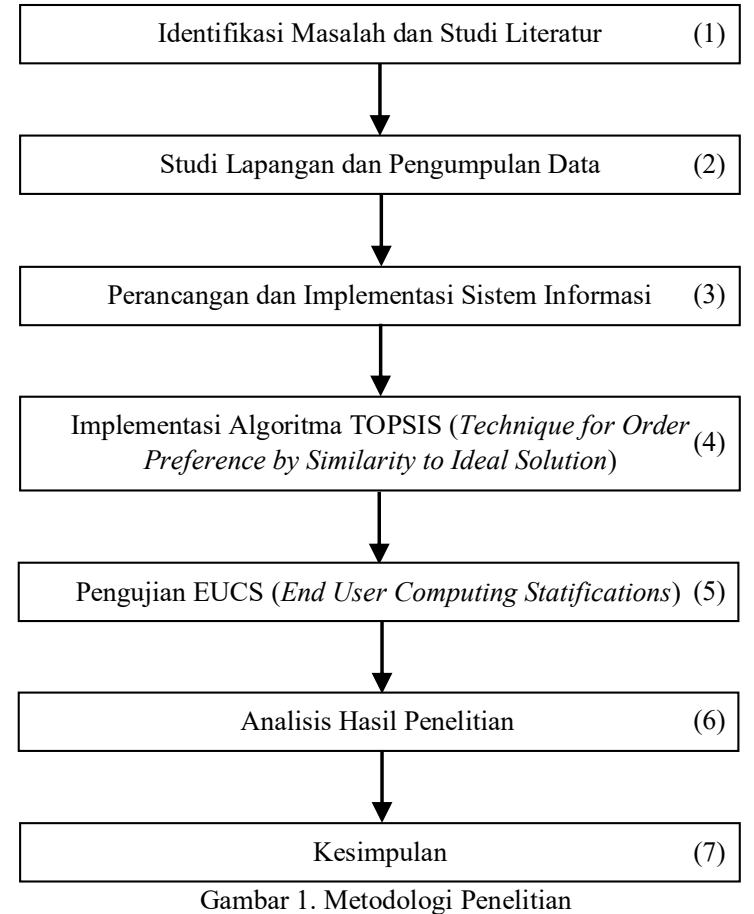

Kriteria pembobotan diperoleh dengan menyebarkan kuesioner kepada kepala sarana \& prasarana dan supervisor. Kriteria penilaian terdiri dari $\mathrm{C} 1=$ kedisiplinan, $\mathrm{C} 2=$ tanggung jawab, C3 = kerja tim, C4 = skill, C5 = akademik, dan C6 = komunikasi. Sehingga diperoleh hasil perhitungan pembobotan kriteria dari kuesioner seperti pada tabel 1.

Tabel 1. Pembobotan Kriteria

\begin{tabular}{ccccccc}
\hline Responden & C1 & C2 & C3 & C4 & C5 & C6 \\
\hline $\begin{array}{c}\text { Kepala Sarana \& } \\
\text { Prasarana }\end{array}$ & 5 & 5 & 5 & 4 & 4 & 5 \\
Supervisor A & 5 & 4 & 5 & 5 & 3 & 5 \\
Supervisor B & 5 & 3 & 5 & 3 & 3 & 5 \\
Supervisor C & 5 & 4 & 5 & 5 & 3 & 5 \\
Supervisor D & 5 & 4 & 5 & 3 & 2 & 5 \\
\hline Hasil & 5 & 4 & 5 & 4 & 3 & 5 \\
\hline
\end{tabular}

Tabel 1 merupakan hasil pembobotan setiap kriteria. Dari hasil kuesioner yang disebarkan, mencari rata - rata setiap kriteria untuk mendapatkan pembobotan kriteria.

\section{TECHNIQUE FOR ORDER PREFERENCE BY SIMILARITY TO IDEAL SOLUTION}

Technique for Order Preference by Similarity to Ideal Solution (TOPSIS) merupakan sebuah algoritma yang digunakan untuk membuat urutan rangking berdasarkan hasil perhitungan, dengan penilaian bobot kinerja yang ditentukan (Brima Surya Prayoga, 2017). Konsep TOPSIS berdasarkan pada pemilihan alternatif yang memiliki jarak terpendek solusi ideal positif dan jarak terpanjang solusi ideal negatif (Madi \& Tap, 2011). Metode ini dikembangkan oleh Kwangsun Yoon Dan Hwang 
Cin-Lai pada tahun 1980. Adapun langkah-langkah dari algoritma TOPSIS adalah sebagai berikut:

- Membentuk matriks keputusan yang ternormalisasi dengan persamaan (1).

$r_{i j}=\frac{x_{i j}}{\sqrt{\sum_{i=1}^{m} x^{2} i j}}$

Dimana:

$$
\begin{aligned}
& \mathrm{i}=1,2, \ldots, \mathrm{m} \text { dan } \mathrm{j}=1,2, \ldots, \mathrm{n} \\
& r_{i j}=\text { matriks ternomalisasi }[\mathrm{i}][\mathrm{j}] \\
& x_{i j}=\text { matriks keputusan }[\mathrm{i}][\mathrm{j}]
\end{aligned}
$$

- Membentuk matriks keputusan yang ternormalisasi berbobot ditentukan dengan persamaan (2).

$y_{i j}=w_{i} r_{i j}$

Dimana:

$$
\begin{aligned}
& y_{i j}=\text { matriks ternomalisasi berbobot }[\mathrm{i}][\mathrm{j}] \\
& w_{i}=\text { matriks pembobotan kriteria }[\mathrm{i}]
\end{aligned}
$$

- Menentukan matriks solusi ideal positif \& matriks solusi ideal negatif ditentukan dengan persamaan (3) dan (4) .

$$
\begin{aligned}
& A^{+}=\left(y_{1}^{+}, y_{2}^{+}, \ldots, y_{n}^{+}\right) \\
& A^{-}=\left(y_{1}^{-}, y_{2}^{-}, \ldots, y_{n}^{-}\right)
\end{aligned}
$$

Dimana:

$$
\begin{aligned}
& A^{+}=\text {solusi ideal positif } \\
& A^{-}=\text {solusi ideal negatif }
\end{aligned}
$$

$y_{1}^{+} \sim y_{n}^{+}=$nilai maksimal dari matriks terbobot setiap kriteria.

$y_{1}^{-} \sim y_{n}^{-}=$nilai minimal dari matriks terbobot setiap kriteria.

- Menentukan jarak antara nilai setiap alternatif dengan matriks solusi ideal positif \& matriks solusi ideal negatif ditentukan dengan persamaan (5) dan (6).

$$
\begin{aligned}
& D_{i}^{+}=\sqrt{\sum_{j=1}^{n}\left(y_{i}^{+}-y_{i j}\right)^{2}} \\
& D_{i}^{-}=\sqrt{\sum_{j=1}^{n}\left(y_{i j}-y_{i}^{-}\right)^{2}}
\end{aligned}
$$

Dimana:

$$
\begin{aligned}
& D_{i}^{+}=\text {jarak alternatif solusi ideal positif } \\
& D_{i}^{-}=\text {jarak alternatif solusi ideal negatif }
\end{aligned}
$$

- Menentukan nilai preferensi untuk setiap alternatif ditentukan dengan persamaan (7).

$V_{i}=\frac{D_{i}^{-}}{D_{i}^{-}-D_{i}^{+}}$

Dimana:

$V_{i}=$ preferensi pada setiap alternatif

\section{PERANCANGAN SISTEM}

Perancangan sistem informasi penilaian kinerja menggunakan Unified Modelling Language (UML) untuk pembuatan usecase diagram, class diagram dan activity diagram. Berikut ini merupakan gambar usecase diagram yang terdapat pada gambar 2 .

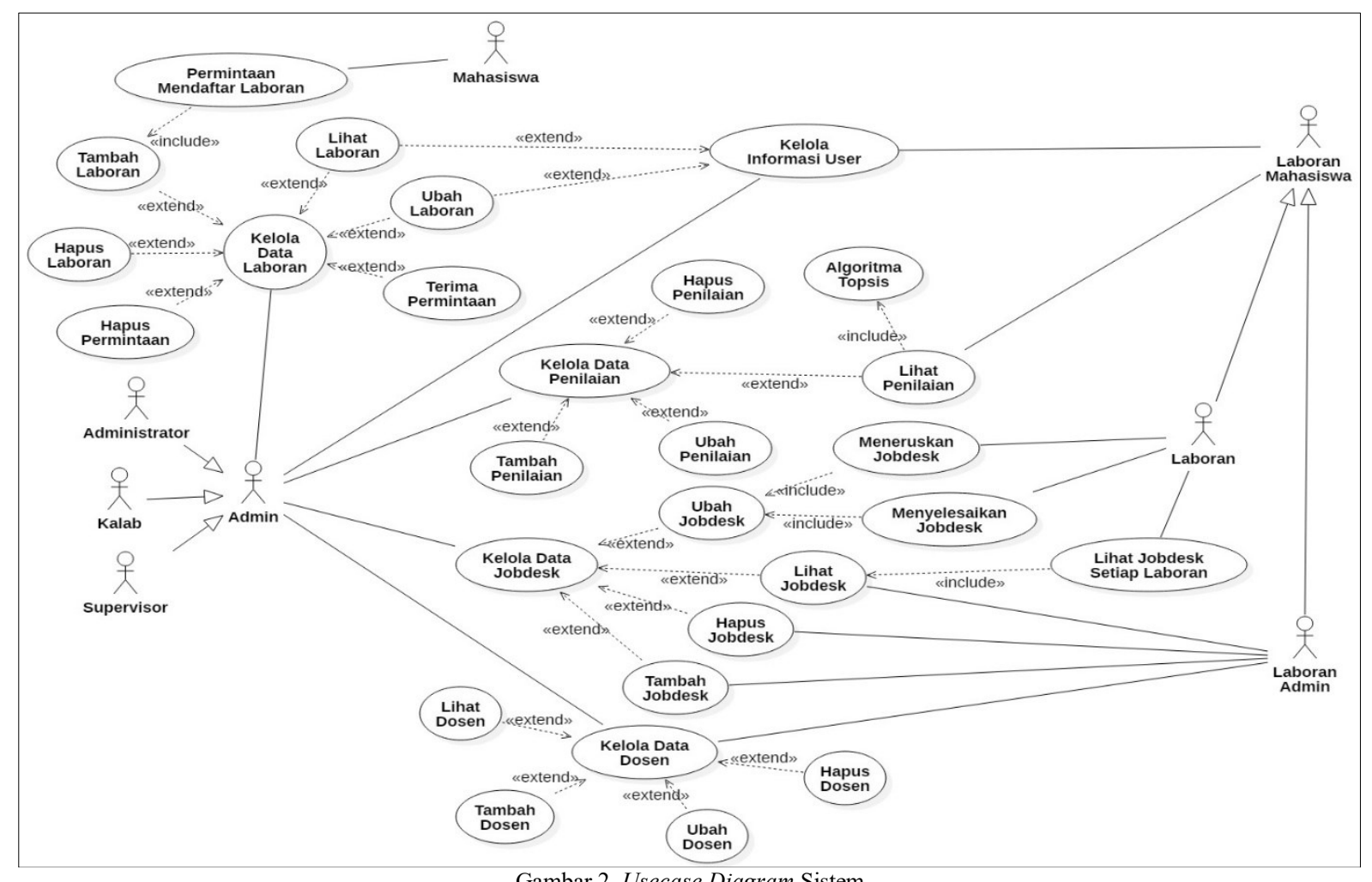

Gambar 2. Usecase Diagram Sistem 
Gambar 2 menjelaskan sistem informasi memiliki 2 user yaitu admin dan laboran yang memiliki hak akses yang berbeda. Untuk user admin lebih ke mengelola keseluruhan sistem, menilai kinerja laboran yang meliputi kelola laboran, kelola jobdesk, kelola informasi user, serta kelola penilaian kinerja laboran. Algoritma TOPSIS berjalan dalam fungsi lihat data penilaian kinerja. Sedangkan user laboran lebih ke pengguna sistem informasi yang meliputi kelola informasi user, lihat jobdesk, serta lihat penilaian kinerja. Class diagram digunakan untuk menggambarkan struktur sistem informasi yang didefinisikan melalui class, sehingga sesuai dengan kebutuhan sistem informasi terdapat pada gambar 3.

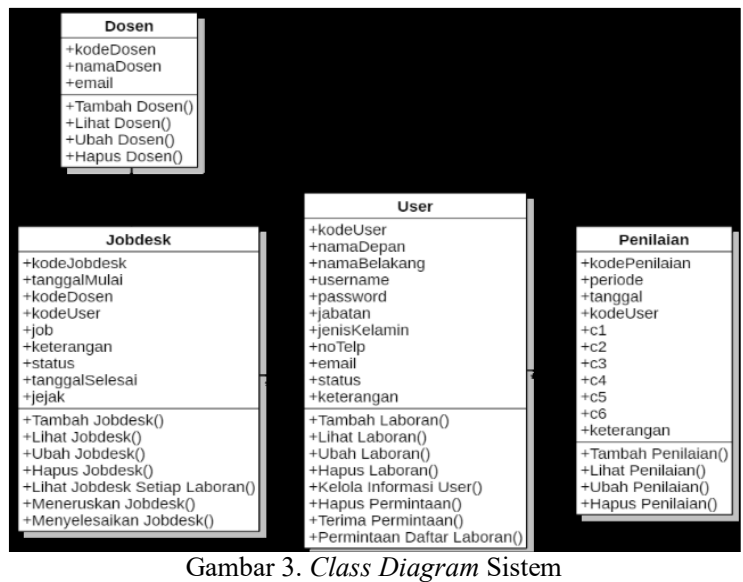

Gambar 3 menjelaskan 4 class yang terdapat pada sistem informasi diantaranya class dosen berisi attribute yang digunakan untuk menyimpan data identitas dosen, class user berisi attribute yang digunakan untuk menyimpan data identitas laboran, class jobdesk berisi attribute yang digunakan untuk menyimpan data tugas yang direquest dari dosen serta class penilaian berisi attribute yang digunakan untuk menyimpan data penilaian yang ketika ditampilkan akan menjalankan algoritma TOPSIS dan menampilkan hasil perhitungan preferensi pada setiap alternatif. Activity diagram digunakan untuk menggambarkan bagaimana sebuah sistem berjalan, sehingga dapat menjelaskan alur program sistem informasi yang terdapat pada gambar 4 .

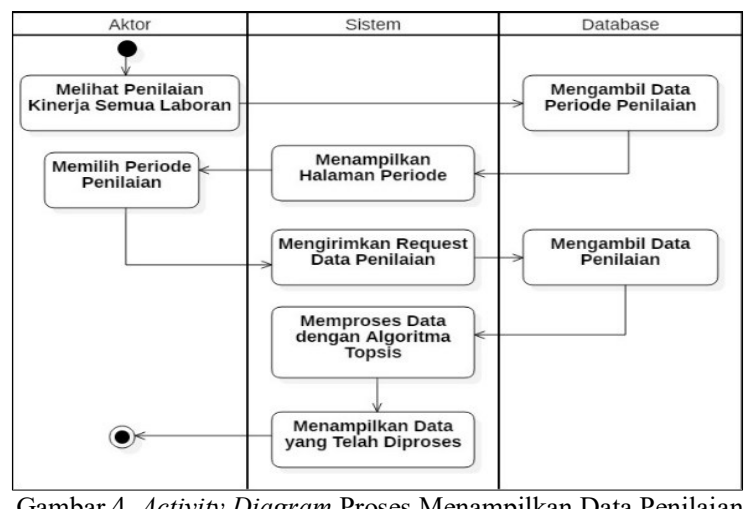

Gambar 4. Activity Diagram Proses Menampilkan Data Penilaian
Gambar 4 menjelaskan activity diagram untuk menampilkan data penilaian kinerja yang dilakukan oleh Admin. Sebelum data penilaian ditampilkan, admin memilih periode penilaian. Data akan diproses melalui perhitungan algoritma TOPSIS dan menampilkan hasil perhitungan berupa nilai preferensi (Vi).

\section{HASIL DAN PEMBAHASAN}

Penelitian ini mengimplementasikan algoritma TOPSIS pada sistem informasi penilaian kinerja. Sistem informasi yang dibangun dapat mengolah data secara dinamis serta dikemas dengan desain dashboard.

\subsection{Flowchart Tampil Penilaian}

Flowchart atau diagram alir digunakan untuk menjelaskan urutan proses dari algoritma. Berikut flowchart proses menampilkan data penilaian dengan algoritma TOPSIS yang terdapat pada gambar 5 .

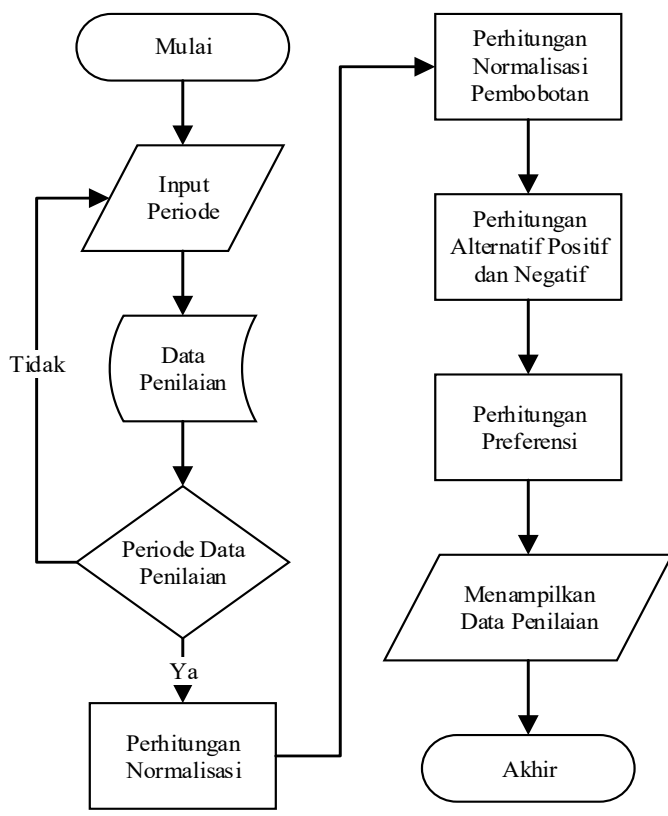

Gambar 5. Flowchart Proses Menampilkan Data Penilaian

Gambar 5 menjelaskan flowchart dari proses menampilkan data penilaian kinerja pegawai laboratorium. Proses diawali dengan memilih periode penilaian. Data penilaian diambil berdasarkan periode yang dipilih. Jika data tidak ditemukan, maka akan kembali pemilihan periode. Jika data ditemukan penilaian, maka data penilaian akan dinormalisasi menggunakan persamaan (1), setelah itu dinormalisasi pembobotan setiap kriteria menggunakan persamaan (2). Langkah selanjutnya menentukan alternatif solusi ideal positif dan negatif menggunakan persamaan (3) dan (4). Kemudian menghitung jarak kedua solusi menggunakan persamaan (5) dan (6). Terakhir menghitung nilai preferensi pada setiap alternatif menggunakan 
persamaan (7). Hasil proses algoritma TOPSIS ditampilkan pada halaman penilaian.

\subsection{Pengujian Algoritma}

Hasil pengujian algoritma TOPSIS menggunakan data penilaian kinerja pegawai laboratorium, dimana hasil pengujian menjadi penentu dalam implementasi algoritma TOPSIS pada sistem penilaian kinerja pegawai laboratorium. Adapun rating penilaian kinerja pegawai meliputi sangat buruk $=1$, buruk $=2$, cukup $=3$, baik $=4$, dan sangat baik $=5$.

\begin{tabular}{|c|c|c|c|c|c|c|}
\hline Pegawai & C1 & $\mathrm{C} 2$ & $\mathrm{C3}$ & C4 & C5 & C6 \\
\hline $\begin{array}{c}\text { Pegawai } \\
\text { A }\end{array}$ & 4 & 4 & 4 & 4 & 5 & 4 \\
\hline $\begin{array}{c}\text { Pegawai } \\
\text { B }\end{array}$ & 3 & 4 & 4 & 4 & 4 & 4 \\
\hline $\begin{array}{c}\text { Pegawai } \\
\text { C }\end{array}$ & 4 & 4 & 4 & 4 & 4 & 4 \\
\hline $\begin{array}{c}\text { Pegawai } \\
\text { D }\end{array}$ & 4 & 4 & 4 & 4 & 5 & 4 \\
\hline $\begin{array}{c}\text { Pegawai } \\
\text { E }\end{array}$ & 3 & 3 & 4 & 4 & 4 & 4 \\
\hline $\begin{array}{c}\text { Pegawai } \\
\text { F }\end{array}$ & 3 & 4 & 4 & 4 & 4 & 4 \\
\hline $\begin{array}{c}\text { Pegawai } \\
\text { G }\end{array}$ & 3 & 4 & 4 & 4 & 4 & 4 \\
\hline $\begin{array}{c}\text { Pegawai } \\
\text { H }\end{array}$ & 4 & 4 & 4 & 4 & 4 & 4 \\
\hline Pegawai I & 4 & 4 & 4 & 4 & 4 & 4 \\
\hline Pegawai J & 4 & 4 & 4 & 4 & 5 & 4 \\
\hline $\begin{array}{l}\text { Pegawai } \\
\text { K }\end{array}$ & 3 & 4 & 4 & 4 & 3 & 4 \\
\hline $\begin{array}{l}\text { Pegawai } \\
\text { L }\end{array}$ & 4 & 4 & 4 & 4 & 4 & 4 \\
\hline
\end{tabular}

Tabel 2 merupakan data penilaian kinerja pegawai, dimana terdapat enam kriteria penilaian meliputi kedisiplinan, tanggung jawab, kerja tim, skill, akademik, dan komunikasi. Langkah pertama, menormalisasi matriks data penilaian seperti pada contoh perhitungan normalisasi dibawah.

$x_{1}=\sqrt{\begin{array}{c}(4)^{2}+(3)^{2}+(4)^{2}+(4)^{2}+(3)^{2}+(3)^{2}+ \\ (3)^{2}+(4)^{2}+(4)^{2}+(4)^{2}+(3)^{2}+(4)^{2}\end{array}}$

$x_{1}=12.53$

$r_{11}=\frac{4}{12.53}=0.32$

Berikut tabel 3 hasil normalisasi matriks data penilaian.

\begin{tabular}{ccccccc}
\multicolumn{7}{c}{ Tabel 3. Hasil Normalisasi } \\
\hline Pegawai & C1 & C2 & C3 & C4 & C5 & C6 \\
\hline Pegawai A & 0.32 & 0.29 & 0.29 & 0.29 & 0.34 & 0.29 \\
Pegawai B & 0.24 & 0.29 & 0.29 & 0.29 & 0.27 & 0.29 \\
Pegawai C & 0.32 & 0.29 & 0.29 & 0.29 & 0.27 & 0.29 \\
Pegawai D & 0.32 & 0.29 & 0.29 & 0.29 & 0.34 & 0.29 \\
Pegawai E & 0.24 & 0.22 & 0.29 & 0.29 & 0.27 & 0.29 \\
Pegawai F & 0.24 & 0.29 & 0.29 & 0.29 & 0.27 & 0.29 \\
Pegawai G & 0.24 & 0.29 & 0.29 & 0.29 & 0.27 & 0.29 \\
Pegawai H & 0.32 & 0.29 & 0.29 & 0.29 & 0.27 & 0.29 \\
\hline
\end{tabular}

\begin{tabular}{ccccccc}
\hline Pegawai & C1 & C2 & C3 & C4 & C5 & C6 \\
\hline Pegawai I & 0.32 & 0.29 & 0.29 & 0.29 & 0.27 & 0.29 \\
Pegawai J & 0.32 & 0.29 & 0.29 & 0.29 & 0.34 & 0.29 \\
Pegawai K & 0.24 & 0.29 & 0.29 & 0.29 & 0.21 & 0.29 \\
Pegawai L & 0.32 & 0.29 & 0.29 & 0.29 & 0.27 & 0.29 \\
\hline
\end{tabular}

Tabel 3 merupakan hasil normalisasi matriks data penilaian, dimana data penilaian menjadi matriks keputusan yang ternormalisasi dengan persamaan (1). Langkah kedua, menormalisasikan pembobotan matriks keputusan dengan setiap pembobotan kriteria yang telah ditentukan pada data penilaian.

$$
\begin{aligned}
& y_{11}=5 * 0.32=1.60 \\
& y_{12}=4 * 0.29=1.18 \\
& y_{13}=5 * 0.29=1.44 \\
& y_{14}=4 * 0.29=1.15 \\
& y_{15}=3 * 0.34=1.03 \\
& y_{16}=5 * 0.29=1.44
\end{aligned}
$$

Berikut tabel 4 hasil normalisasi pembobotan kriteria dari matriks keputusan.

Tabel 4. Hasil Normalisasi Pembobotan

\begin{tabular}{ccccccc}
\hline Pegawai & C1 & C2 & C3 & C4 & C5 & C6 \\
\hline Pegawai A & 1.60 & 1.18 & 1.44 & 1.15 & 1.03 & 1.44 \\
Pegawai B & 1.20 & 1.18 & 1.44 & 1.15 & 0.82 & 1.44 \\
Pegawai C & 1.60 & 1.18 & 1.44 & 1.15 & 0.82 & 1.44 \\
Pegawai D & 1.60 & 1.18 & 1.44 & 1.15 & 1.03 & 1.44 \\
Pegawai E & 1.20 & 0.88 & 1.44 & 1.15 & 0.82 & 1.44 \\
Pegawai F & 1.20 & 1.18 & 1.44 & 1.15 & 0.82 & 1.44 \\
Pegawai G & 1.20 & 1.18 & 1.44 & 1.15 & 0.82 & 1.44 \\
Pegawai H & 1.60 & 1.18 & 1.44 & 1.15 & 0.82 & 1.44 \\
Pegawai I & 1.60 & 1.18 & 1.44 & 1.15 & 0.82 & 1.44 \\
Pegawai J & 1.60 & 1.18 & 1.44 & 1.15 & 1.03 & 1.44 \\
Pegawai K & 1.20 & 1.18 & 1.44 & 1.15 & 0.62 & 1.44 \\
Pegawai L & 1.60 & 1.18 & 1.44 & 1.15 & 0.82 & 1.44 \\
\hline
\end{tabular}

Tabel 4 merupakan hasil normalisasi pembobotan kriteria, dimana pembobotan kriteria dilihat dari prioritas penilaian dengan persamaan (2). Langkah ketiga, menentukan alternatif solusi ideal positif dan negatif.

$$
\begin{aligned}
& A^{+}=\operatorname{Max}\left(\begin{array}{l}
1.60,1.20,1.60,1.60,1.20,1.20 \\
1.20,1.60,1.60,1.60,1.20,1.60
\end{array}\right) \\
& A^{+}=1.60 \\
& A^{-}=\operatorname{Min}\left(\begin{array}{l}
1.60,1.20,1.60,1.60,1.20,1.20 \\
1.20,1.60,1.60,1.60,1.20,1.60
\end{array}\right) \\
& A^{-}=1.20
\end{aligned}
$$

Berikut tabel 5 hasil alternatif solusi ideal positif dan negatif.

Tabel 5. Hasil Solusi Ideal Positif dan Negatif

\begin{tabular}{ccccccc}
\hline & C1 & C2 & C3 & C4 & C5 & C6 \\
\hline $\begin{array}{c}\text { Ideal } \\
\text { Negatif }\end{array}$ & 1.20 & 0.88 & 1.44 & 1.15 & 0.62 & 1.44 \\
$\begin{array}{c}\text { Ideal } \\
\text { Positif }\end{array}$ & 1.60 & 1.18 & 1.44 & 1.15 & 1.03 & 1.44 \\
\hline
\end{tabular}


Tabel 5 merupakan hasil solusi ideal positif dan negatif, dimana ideal negatif merupakan nilai terkecil setiap kriteria dan ideal positif merupakan nilai terbesar setiap kriteria ditentukan dengan persamaan (3) dan (4). Langkah keempat, menentukan jarak setiap alternatif ideal positif.

$D_{1}^{+}=\sqrt{\begin{array}{l}(1.60-1.60)^{2}+(1.18-1.18)^{2}+ \\ (0.87-0.87)^{2}+(1.15-1.15)^{2}+ \\ (1.03-1.03)^{2}+(1.44-1.44)^{2}\end{array}}=0$

Berikut tabel 6 hasil dari jarak setiap alternatif ideal positif.

Tabel 6. Hasil Jarak Ideal Positif

\begin{tabular}{cc}
\hline Pegawai & Preferensi \\
\hline Pegawai A & 0.00 \\
Pegawai B & 0.45 \\
Pegawai C & 0.21 \\
Pegawai D & 0.00 \\
Pegawai E & 0.54 \\
Pegawai F & 0.45 \\
Pegawai G & 0.45 \\
Pegawai H & 0.21 \\
Pegawai I & 0.21 \\
Pegawai J & 0.00 \\
Pegawai K & 0.57 \\
Pegawai L & 0.21 \\
\hline
\end{tabular}

Tabel 6 merupakan hasil dari perhitungan jarak ideal positif, dimana jarak ideal positif ditentukan dengan persamaan (5). Langkah kelima, menentukan jarak setiap alternatif ideal negatif.

$D_{1}^{-}=\sqrt{\begin{array}{l}(1.60-1.20)^{2}+(1.18-0.88)^{2}+ \\ (0.87-0.87)^{2}+(1.15-1.15)^{2}+ \\ (1.03-0.62)^{2}+(1.44-1.44)^{2}\end{array}}=0.64$

Berikut tabel 7 hasil dari jarak setiap alternatif ideal negatif.

Tabel 7. Hasil Jarak Negatif

\begin{tabular}{cc}
\multicolumn{2}{c}{ Tabel 7. Hasil Jarak Negatif } \\
\hline Pegawai & Preferensi \\
\hline Pegawai A & 0.64 \\
Pegawai B & 0.36 \\
Pegawai C & 0.54 \\
Pegawai D & 0.64 \\
Pegawai E & 0.21 \\
Pegawai F & 0.36 \\
Pegawai G & 0.36 \\
Pegawai H & 0.54 \\
Pegawai I & 0.54 \\
Pegawai J & 0.64 \\
Pegawai K & 0.29 \\
Pegawai L & 0.54
\end{tabular}

Tabel 7 merupakan hasil perhitungan jarak ideal negatif, dimana jarak ideal negatif ditentukan dengan persamaan (6). Langkah keenam, menentukan hasil akhir nilai preferensi setiap alternatif dengan persamaan (7).

$V_{1}=\frac{0.64}{0.64-0}=1$

Berikut tabel 8 hasil akhir nilai preferensi penilaian kinerja pegawai laboratorium.

\begin{tabular}{cc} 
Tabel 8. Hasil Preferensi Penilaian Kinerja Pegawai \\
\hline Pegawai & Preferensi \\
\hline Pegawai A & 1 \\
Pegawai D & 1 \\
Pegawai J & 1 \\
Pegawai I & 0.7224 \\
Pegawai C & 0.7224 \\
Pegawai L & 0.7224 \\
Pegawai H & 0.7224 \\
Pegawai G & 0.4443 \\
Pegawai B & 0.4443 \\
Pegawai F & 0.4443 \\
Pegawai K & 0.3388 \\
Pegawai E & 0.2776 \\
\hline
\end{tabular}

Tabel 8 merupakan hasil perhitungan akhir nilai preferensi penilaian kinerja pegawai laboratorium, dimana nilai akhir preferensi di urutkan berdasarkan terbesar ke terkecil untuk mempermudah evaluasi kinerja pegawai setiap periode. Terdapat 3 urutan teratas yaitu Pegawai A, Pegawai D, dan Pegawai J dengan nilai preferensi 1, dimana penilaian yang diberikan sama. Langkah terakhir menyajikan data penilaian menggunakan tampilan web bintang 1 sampai 5, untuk memberikan UI yang menarik.

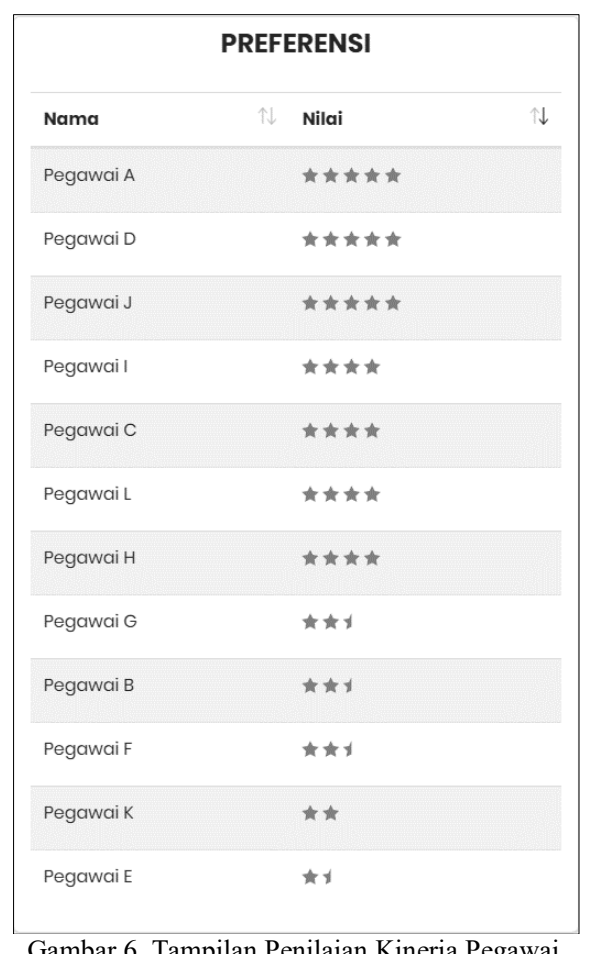

Gambar 6. Tampilan Penilaian Kinerja Pegawai 
Gambar 6 merupakan tampilan nilai preferensi, dimana nilai preferensi diganti dengan simbol bintang antara 1 sampai dengan 5, untuk memberikan pelayanan $U X$ yang baik. Adapun flowchart dari algoritma TOPSIS yang terdiri dari 4 tahap proses perhitungan, sehingga menghasilkan nilai preferensi akhir yang telah diurutkan berdasarkan nilai tertinggi seperti pada tabel 8 .

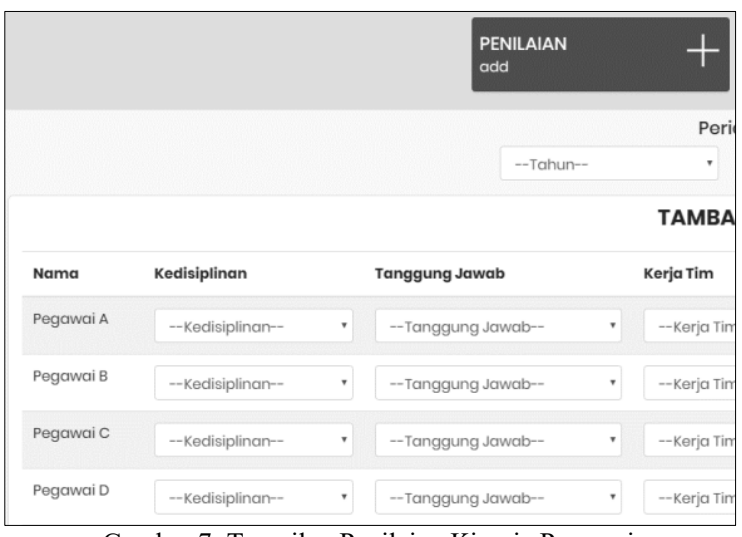

Gambar 7. Tampilan Penilaian Kinerja Pegawai

Gambar 7 merupakan tampilan untuk memasukkan data penilaian kinerja pegawai. Penempatan field penilaian pegawai disajikan dengan select option sehingga mudah untuk dioperasikan. Nilai select option berupa angka 1 sampai dengan 5, dimana nilai 1 untuk sangat buruk, nilai 2 untuk buruk, nilai 3 untuk cukup, nilai 4 nilai baik, dan nilai 5 untuk sangat baik. Tampilan Data penilaian akan tersimpan pada database berupa nilai 1 sampai dengan 5 setiap record.

\subsection{Analisis EUCS}

Analisis kelayakan sistem dilakukan menggunakan model End User Computing Statifications (EUCS) dengan lima responden yaitu satu kepala sarana \& prasarana dan empat supervisor. Variabel yang digunakan adalah Content, Accuracy, Format, Ease Of Use, dan Timeliness. Dengan skor penilaian Sangat Puas (4), Puas (3), Tidak Puas (2) dan Sangat Tidak Puas (1). Pertanyaan yang diajukan adalah sebagai berikut:
CONTENT:

- Website menyediakan informasi yang dibutuhkan oleh pengguna dengan tepat dan benar.

- Website menyediakan informasi sesuai dengan kebutuhan pengguna.

- Website mempunyai fungsi - fungsi yang mendukung proses pelayanan pegawai laboratorium.

- Website mempunyai keseragaman informasi sesuai dengan kebutuhan pengguna.

ACCURACY:

- Website memberikan informasi yang akurat sesuai dengan keinginan pengguna.

- Website menyediakan informasi sesuai dengan hak akses pengguna.

- Website memberikan hasil sesuai dengan informasi yang dibutuhkan pengguna.

- Website menyajikan hasil perhitungan data dengan benar.

\section{FORMAT:}

- Tampilan Website tidak membingungkan pengguna.

- Tampilan Website menarik.

- Layanan Website sudah mewakili kebutuhan pengguna.

- Tata letak konten telah memenuhi syarat.

EASE OF USE:

- Website memberikan petunjuk penggunaan sistem.

- Pengguna dapat menjalankan fungsi pada Website tanpa kesulitan.

- Navigasi yang ada pada Website tidak membingungkan pengguna.

- Website dapat dioprasikan dengan mudah oleh pengguna.

TIMELINESS:

- $\quad$ Situs Website dapat diakses dengan cepat.

- Waktu tanggap dalam situs Website baik.

- Informasi Website selalu terubah.

- Pemrosesan data cepat yang dieksekusi pada tampilan.

Tabel 9. Hasil Kuesioner EUCS

\begin{tabular}{cccccc}
\hline \multirow{2}{*}{ Responden } & \multicolumn{4}{c}{ Mean } \\
\cline { 2 - 5 } & Content & Accuracy & Format & Ease Of Use \\
\hline Kepala Sarana \& Prasarana & 3.5 & 3.75 & 3.75 & 3 & 3.25 \\
Supervisor A & 3.75 & 3 & 4 & 3.25 & 3.25 \\
Supervisor B & 3.25 & 3.25 & 3.5 & 3.25 & 3.5 \\
Supervisor C & 3.25 & 3.25 & 3.75 & 3.15 \\
Supervisor D & 3.25 & 3.25 & 3.75 & 3.75 \\
\hline Total rata - rata & 3.4 & 3.3 & 3.75 & \multicolumn{2}{c}{3.41} \\
\hline Hasil & &
\end{tabular}


Berdasarkan hasil pengujian EUCS pada tabel 9, pengujian dilakukan dengan lima responden yaitu satu kepala sarana \& prasarana dan empat supervisor. Hasil pengujian sistem memperoleh skor 3.41 dari total nilai kepuasan (4) yang tergolong dalam kategori puas. Skor tersebut telah menunjukkan bahwa sistem informasi penilaian kinerja pegawai telah layak dan dapat diterima oleh user.

\section{KESIMPULAN}

Berdasarkan hasil dan pembahasan, secara keseluruhan pengujian algoritma TOPSIS ini telah mampu menghitung penilaian kinerja dengan hasil seperti pada tabel 8 , dimana terdapat nilai preferensi tertinggi yaitu 1 yang diperoleh 3 dari 12 orang pegawai pada pengujian algoritma TOPSIS. Penyajian sistem informasi ditampilkan menggunakan desain dashboard. Hasil akhir dari penelitian berupa nilai preferensi (Vi) yang ditampilkan dengan bintang antara 1 sampai dengan 5 yang menunjukan tingkat kinerja pegawai laboratorium setiap periode, sehingga bisa menjadi sarana untuk memanajemen sumber daya manusia guna menjaga kualitas dan kinerja pegawai laboratorium. Pengujian EUCS menghasilkan skor 3.14 dari total nilai kepuasan 4, sehingga tergolong dalam kategori puas yang layak dan dapat diterima oleh user.

Dengan adanya sistem informasi ini, kepala sarana \& prasarana dan supervisor dapat mengontrol tingkat kinerja pegawai pada setiap periode.

Penelitian selanjutnya disarankan menggunakan algoritma Analytic Hierarchy Process (AHP) untuk penentuan bobot kriteria penilaian, sehingga hasil akhir nilai preferensi (Vi) bisa lebih tepat. Dikarenakan bobot kriteria penilaian sangat berpengaruh pada hasil akhir nilai preferensi (Vi) penilaian.

\section{DAFTAR PUSTAKA}

BRIMA SURYA PRAYOGA, W.M.P., 2017. Sistem Pendukung Keputusan Jurusan Di Man Ii Yogyakarta Menggunakan Algoritma Topsis. Seminar Nasional Teknologi Informasi Dan Multi Media, pp.1-6.

DAMAYANTI, A.S., MURSITYO, Y.T. \& HERLAMBANG, A.D., 2018. Evaluasi Kepuasan Pengguna Aplikasi Tapp Market Menggunakan Metode EUCS (End User Computing Satisfaction). Jurnal Pengembangan Teknologi Informasi dan Ilmu Komputer, 2(11), pp.4833-4839.

DSN, C., 2015. TOPSIS. [online] Tersedia di: $<$ https:/cahyadsn.phpindonesia.id/extra/top sis.v2.php $>$ [Diakses 26 Maret 2019].

FEBRIYATI, M.N., SOPHAN, M.K. \& YUNITARINI, R., 2016. Perbandingan saw dan topsis untuk open recruitment warga laboratorium teknik informatika di universitas trunojoyo madura. Jurnal Simantec, [online] 5(3), p.233. Tersedia di: $<$ http://journal.trunojoyo.ac.id/simantec/arti cle/view/2348> [Diakses 15 Oktober 2019].

FIRMANTO, B., SOEKOTJO, H. \& DACHLAN, H.S., 2016. Perbandingan Kinerja Algoritma Promethee dan Topsis Untuk Pemilihan Guru Teladan. Junal Penelitian Pendidikan IPA, [online] 2(1), pp.81-86. Tersedia di: $<$ https://journal.unesa.ac.id/index.php/jppip a/article/view/3089/1947> [Diakses 15 Oktober 2019].

HADI, H.N. \& MAHMUDY, W.F., 2015. Penilaian Prestasi Kinerja Pegawai Menggunakan Fuzzy Tsukamoto. Jurnal Teknologi Informasi dan Ilmu Komputer, 2(1), p.41.

KEPENDIDIKAN, K.P. \& K.D.J.P.T.D.P. \& T., 2014. Pedoman Umum.

MADI, E.N. \& TAP, A.O.M., 2011. Fuzzy TOPSIS Method in the Selection of Investment Boards by Incorporating Operational Risks. Proceedings of the World Congress on Engineering, 1, pp.6-10.

MARDIANA, T., 2017. Keputusan Pemberian Pinjaman Pada Koperasi Karyawan. Jurnal Khatulistiwa Informatika, V(2), pp.128138.

PRASETYOWATI, A. \& KUSHARTANTI, R., 2018. User Satisfaction Analysis of Primary Care Information Systems in Semarang City with EUCS Model. Unnes Journal of Public Health, 2(1), pp.1-10.

SHAOUT, A. \& YOUSIF, M.K., 2014. Performance Evaluation - Methods and Techniques Survey. International Journal of Computer and Information Technology, 03(05), p.2279764.

SURYA, C., 2018. Penilaian Kinerja Dosen Menggunakan Metode TOPSIS (Studi Kasus : Amik Mitra Gama). Jurnal RESTI (Rekayasa Sistem dan Teknologi Informasi), 2(1), pp.322-329. 
Halaman ini sengaja dikosongkan 